\title{
Effect of developmental temperature on swimming performance of zebrafish (Danio rerio) juveniles
}

\author{
Dimitris G. Sfakianakis • Ioannis Leris • \\ Maroudio Kentouri
}

Received: 5 July 2010 / Accepted: 11 November 2010/Published online: 23 November 2010

(C) Springer Science+Business Media B.V. 2010

\begin{abstract}
It is widely known that water temperature affects the swimming capacity of fish. But the effect of the rearing temperature on the swimming ability of the fish at later stages, has not had similar attention. In this study, four populations of zebrafish, were reared in different water temperatures $(22,25,28$ and $31^{\circ} \mathrm{C}$ ) and after being acclimatized in a common temperature $\left(26.5^{\circ} \mathrm{C}\right)$ for over a month, they were subjected to swimming trials in order to evaluate the maximum relative critical velocity $\left(R U_{\text {crit }}\right)$ in each case. Fish that were reared in $22^{\circ} \mathrm{C}$ showed statistically significant lower performance than the ones reared in $31^{\circ} \mathrm{C}(7.72 \pm 0.17$ vs. $8.79 \pm 0.28$, means \pm S.E. $)$. Possible explanations for the observed differentiation could be the effect of early life temperature on fish muscle ontogeny or on body shape.
\end{abstract}

Keywords Critical velocity $\cdot \mathrm{U}_{\text {crit }} \cdot \mathrm{RU}_{\text {crit }} \cdot$ Rearing . Plasticity

\section{Introduction}

Swimming performance is a biological characteristic that has a very important role on fish survival

D. G. Sfakianakis $(\bowtie) \cdot I$. Leris $\cdot$ M. Kentouri

Biology Department, University of Crete, P.O. Box 2208, Vasilika Vouton,

71409 Heraklion, Crete, Greece

e-mail: sfak@biology.uoc.gr
(Jones et al. 1974), as it can strongly affect food capture, mating success and the avoidance of unfavourable situations (Drücker 1996). Moreover, it has been stated that the ability of locomotion is a main trait that defines to a great extent the Darwinian fitness (Reidy et al. 2000). Most of the environmental factors that affect swimming capacity have already been studied thoroughly and in a wide range of species. Among them, temperature (Fuiman and Batty 1997; Beamish 1978; Wieser and Kaufmann 1998; Ojanguren and Brana 2000; Dickson et al. 2002; Koumoundouros et al. 2002a, b; Wilson et al. 2002; Franklin et al. 2003), oxygen (Beamish 1978; Hammer 1995; Korsmeyer et al. 1996; Steffensen and Farrell 1998) and carbon dioxide concentration (Dahlberg et al. 1968; Beamish 1978), pollutants (Howard 1975; Beamish 1978; Beaumont et al. 2000; Randall and Tsui 2002; Wicks et al. 2002), salinity (Beamish 1978), light and photoperiod (Beamish 1978; Hammer 1995; Young et al. 2004) seem to play a particularly important role.

Temperature itself seems to be the most important environmental factor that affects the life of fish. Besides swimming performance, it has been shown to affect growth, metabolism, time of hatching (Herzig and Winkler 1986), development (Herzig and Winkler 1986; Fukuhara 1990; Polo et al. 1991; Gibson and Johnston 1995; Lein et al. 1997), yolk absorption (Fukuhara 1990), muscle ontogeny and development (Johnston 1981, 1993, 2006; Wilkes et al. 2001; Johnston et al. 2009), 
ontogeny of internal organs (Fukuhara 1990; Gibson and Johnston 1995), external morphology (Lindsey 1988; Wimberger 1992; Tudela 1999; Koumoundouros et al. 2001a; Pakkasmaa and Piironen 2001; Cabral et al. 2003; Silva 2003; Turan 2004), meristic characters (Turan 2004), appearance of skeletal deformities (Polo et al. 1991; Koumoundouros et al. 2001b), sex determination (Baroiller et al. 1999; Pavlidis et al. 2000; Koumoundouros et al. 2002a) and the overall survival (Fukuhara 1990; Lein et al. 1997) and lifespan of fish (Malek et al. 2004). Although the effect of swimming temperature on the performance of fish has been studied thoroughly and in a wide range of species, there are only a few studies focusing on the impact of rearing temperature on the swimming performance of adult fish (i.e. Koumoundouros et al. 2009).

Zebrafish is a small, colourful, tropical fish inhabiting small ponds and slow moving streams in Southeast Asia (Talwar and Jhingran 1991). For the past few decades, it has been a very important model-organism in research fields such as Genetics, Neurophysiology, Developmental Biology and Biomedicine (Amsterdam and Hopkins 2006). Numerous laboratories worldwide are using zebrafish for fundamental or applied research and there is an increasing interest for its use in new research fields (Gerlai 2003). In spite of its popularity as a research tool, only recently did some integrated studies about its biological and ecological characteristics emerge (Engeszer et al. 2007; Spence et al. 2008).

Concerning the temperature range in which zebrafish live and reproduce in the environment, more than one suggestion exists. Froese and Pauly (2010) argue that zebrafish's natural habitat temperature ranges from $18^{\circ} \mathrm{C}$ to $24^{\circ} \mathrm{C}$, whereas Engeszer et al. (2007) report that the observed temperature range for zebrafish in the wild lies between $24.6^{\circ} \mathrm{C}$ and $38.6^{\circ} \mathrm{C}$. Spence et al. (2008) on the other hand, mention that temperature in $D$. rerio's habitats ranges from $6^{\circ} \mathrm{C}$ in the winter to $38^{\circ} \mathrm{C}$ in the summer. Our personal observations throughout many rearing trials showed that the rearing temperatures of $22^{\circ} \mathrm{C}$ and $31^{\circ} \mathrm{C}$ are the lower and upper limit values for successful rearing in the laboratory. At lower or higher - respectively - temperatures, the risk of unsuccessful hatching, mass larvae mortality and severe skeletal malformations throughout the populations, is extremely high.
The purpose of this article is to study the effect of four different rearing temperatures (ranging from $22^{\circ} \mathrm{C}$ to $31^{\circ} \mathrm{C}$ ) on the swimming performance of adult zebrafish.

\section{Materials and methods}

A single batch of eggs of $D$. rerio was obtained from wild type broodstock (ZF WT2 F5, Wageningen Agricultural University, The Netherlands) that was kept in a 301 tank at $28 \pm 0.5^{\circ} \mathrm{C}$ and fed three times per day with industrial dry food in flakes (Sera Vipan, Germany) and three times per week with Artemia sp. nauplii (Instar I). The eggs were collected approximately $2 \mathrm{~h}$ after fertilization, examined under the stereoscope (Olympus, SZX9), selected in terms of quality and submerged for $12-15 \mathrm{~min}$ in hydrogen peroxide $\left(3 \mathrm{ml} \mathrm{l}^{-1}\right)$ for antifungal protection. Afterwards (approximately $3 \mathrm{~h}$ after fertilization), batches of 200 eggs were transferred into hatching devices that were placed in four rearing tanks of 1301 of different water temperatures $\left(22,25,28\right.$ and $\left.31^{\circ} \mathrm{C}\right)$. The regulation of temperature was achieved with the use of electrical thermostat heaters (Aquarium Systems, Visi-Therm, 100-150 W) and coolant device, when needed. The rearing was performed in duplicate $(\mathrm{A}$ and $\mathrm{B})$.

Hatching occurred at $2\left(28\right.$ and $\left.31^{\circ} \mathrm{C}\right), 3\left(25^{\circ} \mathrm{C}\right)$, or 6 days $\left(22^{\circ} \mathrm{C}\right)$ after spawning. Larvae were fed four times per day, initially (at 2 days post hatching, dph) with Paramecium sp. (Blades Biological CO, UK) and later (at $33 \mathrm{dph}$ ) with newly hatched Artemia sp. nauplii (Instar I) (Westerfield 1995). Approximately at $73 \mathrm{dph}$, industrial dry food in flakes was introduced, which consisted the main diet of the fish throughout the acclimation and experimental periods. With every food-type change, a transitional period of three days was applied, at which both food types were provided. At approximately $143 \mathrm{dph}$, the acclimation - to the common temperature of $26.5^{\circ} \mathrm{C}$ - period started and lasted 1.5 month, until the start of the swimming exercises.

Swimming performance trials were carried out in an apparatus described by Koumoundouros et al. (2002b). Water velocity was calibrated by means of an electromagnetic flow-meter (Valeport, Model 801). Fish forward escape was prevented using a mesh screen located at the upstream end of the swimming 
channel. A homogenous current velocity throughout the whole depth and length of the channel was verified by means of dye injected into the swimming channel. Temperature was maintained constant at $26.5^{\circ} \mathrm{C}$ using a thermostat heater, while the oxygen saturation was $>99 \%$.

For the critical velocity $\left(U_{\text {crit }}\right)$ measurements to be valid, the speed tests should be conducted based on the Total Length (TL) of the specimens used (Brett 1964). Therefore, the swimming performance trials were carried out not in one but at 3 different swimming speeds in order to accurately cover different fish sizes. The swimming speeds (and the velocity increments) used to test the fish were - according to their size - the following: 30, 32.5 and $35 \mathrm{~mm} \mathrm{sec}^{-1}$. The TL of the fish was assessed visually before the trial to avoid excess stress from the unnecessary fish handling (Ramsay et al. 2009). If the actual TL (as measured at the end of the experiments on the digital photographs of the anaesthetized fish) differed from the estimated one and therefore from the applied speed and the velocity increment more than $1.25 \mathrm{~mm}$, then the data concerning that fish were discarded. Only male fish were used for the trials, so as to avoid possible sex-dependent differences (Williams and Brett 1987). Fish were starved for $24 \mathrm{~h}$ prior to the swimming trials. Fish were also macroscopically examined prior to the trials for any visible morpho-anatomical malformations. Before the trial, fish were acclimated for $15 \mathrm{~min}$ to the holding tank's conditions and then one fish was placed in the swimming tunnel for $10 \mathrm{~min}$ at a water velocity of $2 \mathrm{TL} \mathrm{sec}^{-1}$. Water velocity increased every $10 \mathrm{~min}$ at a rate of $1 \mathrm{TL} \mathrm{sec}-1$ until the fish fatigued. Fatigue was reached when a fish was carried away by the current, without been able to hold its position in the swimming tunnel or react to visual and acoustic stimuli.

Since body mass can affect metabolism (Hochachka 1987) and body length can affect swimming power output, we assessed both in all groups after treatments (McClelland et al. 2006). To do so, fish were anaesthetized (ethylenglycol-monophenylether, Merck, $0.2-0.3 \mathrm{ml} \mathrm{l}^{-1}$ ), individually photographed using a digital camera (Olympus, Camedia C3030 Zoom) and weighed (M, $0.001 \mathrm{~g})$, while the maximum body width (BW) was measured under a stereoscope $(0.01 \mathrm{~mm})$. Landmarks were also placed to the obtained pictures using an image processing software (tpsDig2, Rohlf, version 5.0.3.32), for the accurate measurement of the
TL, maximum body depth $\left(\mathrm{BD}_{\max }\right)$, body depth at the anus (BD) and caudal peduncle depth (CpD). Moreover, selective double staining of cartilage and bone tissue was performed on the specimens after the trials and the stained samples were examined under a stereoscope for skeletal deformities (Divanach et al. 1997; Koumoundouros et al. 1997a, b, 2001b). The abnormal fish were discarded from the analysis.

Critical swimming speed was calculated using the equation introduced by Brett (1964):

$U_{c r i t}=U_{i}+U_{i i}\left(\frac{T_{i}}{T_{i i}}\right)$

where $U_{\mathrm{i}}$ is the highest velocity maintained for the whole $10 \mathrm{~min}(\mathrm{~mm} \mathrm{sec}-1), U_{\mathrm{ii}}$ is the velocity increment $\left(30,32.5\right.$ and $\left.35 \mathrm{~mm} \mathrm{sec}^{-1}\right), T_{\mathrm{i}}$ is the time elapsed at fatigue velocity and $T_{\mathrm{ii}}$ is the time between velocity increments (10 $\mathrm{min})$.

To compare the swimming performance of many individuals that varied in length, the $U_{\text {crit }}$ had to be transformed to a new value that would be independent of the factor TL. So, after calculating the $U_{\text {crit }}$, the relative critical swimming speed $\left(R U_{\text {crit }}\right)$ for every fish was calculated using this equation:

$R U_{\text {crit }}=\frac{U_{\text {crit }}}{T L} \quad$ (Beamish 1978)

As the assumption of homogeneity of variances was not fulfilled, the Mann-Whitney U-test was used for the comparison of swimming performance between the four different temperatures and the 2 replicates, after the appropriate correction for tied measurements (Sokal and Rohlf 1995). The non parametric Kruskal-Wallis was used to test the effect of temperature on $R U_{\text {crit }}$ (Sokal and Rohlf 1995).

All experimental procedures were in accordance with the European Communities Council directive (86/609/EEC) for the care and use of laboratory animals and approved by the University of Crete research committee.

\section{Results}

The relative critical velocities measured for the individuals of each duplicate of the four temperature groups are presented in Table 1. Statistical analysis showed a significant influence of the factor, rearing temperature, on the swimming performance of the 
Table $1 R U_{\text {crit }}(\mathrm{SE}$, standard error) for each duplicate (A and B) and for each temperature group $\left(22,25,28\right.$ and $\left.31^{\circ} \mathrm{C}\right)$

${ }^{\mathrm{a}} p<0.05$ (Mann-Whitney U-test)

\begin{tabular}{llcccccc}
\hline Temperature & Dup. & $R U_{\text {crit }}\left(\mathrm{TL} \mathrm{sec}^{-1}\right)$ & $\mathrm{SE}$ & $\mathrm{N}$ & Average $R U_{\text {crit }}$ & $\mathrm{SE}$ & $p$ \\
\hline $22^{\circ} \mathrm{C}$ & $\mathrm{A}$ & 7.68 & 0.17 & 10 & 7.72 & 0.17 & $\mathrm{a}$ \\
& $\mathrm{B}$ & 7.76 & 0.30 & 11 & & & \\
$25^{\circ} \mathrm{C}$ & $\mathrm{A}$ & 8.05 & 0.42 & 8 & 8.13 & 0.27 & - \\
& $\mathrm{B}$ & 8.20 & 0.36 & 9 & & & \\
$28^{\circ} \mathrm{C}$ & $\mathrm{A}$ & 8.23 & 0.33 & 9 & 8.36 & 0.28 & - \\
& $\mathrm{B}$ & 8.46 & 0.44 & 11 & & & \\
$31^{\circ} \mathrm{C}$ & $\mathrm{A}$ & 8.69 & 0.37 & 10 & 8.79 & 0.28 & $\mathrm{a}$ \\
& $\mathrm{B}$ & 8.89 & 0.44 & 10 & & & \\
& & & & & & &
\end{tabular}

juveniles ( $p<0.05$, Kruskal-Wallis). At all temperature regimes, by means of Mann-Whitney U-test, no significant differences were revealed between the two duplicates.

Fish raised at $31^{\circ} \mathrm{C}$ have achieved the higher swimming performances in terms of $R U_{\text {crit }}$, while the ones reared in $22^{\circ} \mathrm{C}$ had the worst performance $(p<$ 0.05 , Mann-Whitney). Fish cultured in 25 and $28^{\circ} \mathrm{C}$ achieved intermediate critical swimming speeds although not significantly different from the others (Table 1).

The measurements of the morphometric characters performed after the swimming trials as well as the ones that derived from the morphometric analysis of the landmarks placed on the specimen photographs are presented in Table 2.

For those characters, the performed Mann-Whitney U-tests revealed no statistical significant differences between the fish raised at the different temperature regimes $(p>0.05)$.

\section{Discussion}

Fish are known to react to their environment's fluctuations in all possible ways and it is an evolutionary imperative to try and adjust to these changes. Zebrafish, although considered to be a tropical fish, inhabits ecosystems with "monsoon climate", that present an extraordinary seasonal variation of temperatures that can range from as low as $6^{\circ} \mathrm{C}$ in winter to over $38^{\circ} \mathrm{C}$ in summer (Spence et al. 2008). With the phenomenon of global warming being more and more imminent, the effects that such a wide range of temperatures can have on many important processes and aspects of the fish life are certainly worth of extensive study.

Developmental temperature plays an important role on the subsequent life of fish. On the present study the role of early rearing temperature on the swimming capacity of zebrafish juveniles was examined. The results showed that fish reared at $31{ }^{\circ} \mathrm{C}$ have a higher swimming ability $\left(8.79 \mathrm{TL} \mathrm{sec}{ }^{-1}\right)$ than fish reared at $22^{\circ} \mathrm{C}\left(7.72 \mathrm{TL} \mathrm{sec}{ }^{-1}\right)$. Fish raised at the two intermediate temperatures $\left(25\right.$ and $\left.28^{\circ} \mathrm{C}\right)$, although not statistically different from either one of the extreme temperatures, they seem to perform better than the fish of $22^{\circ} \mathrm{C}$ and worse than the fish of $31^{\circ} \mathrm{C}$ (8.13 and 8.36 TL sec ${ }^{-1}$ respectively).

Swimming ability of zebrafish has been studied before in the case of larval (i.e. Budick and O'Malley 2000; Levin et al. 2004) and adult specimens (Plaut and Gordon 1994; Plaut 2000; McClelland et al. 2006; Widmer et al. 2006) but never in respect to developmental temperature. Plaut (2000) studied the effect of the fin size on the swimming performance of

Table 2 Morphometric characters ( $S D$ standard deviation). $T L$ total length, $W$ weight, $B W$ body width, $B D$ max maximum body depth, $B D$ body depth (at anus), $C p D$ caudal peduncle depth

\begin{tabular}{|c|c|c|c|c|c|c|c|c|c|c|c|c|}
\hline Temp. & $\mathrm{TL}(\mathrm{mm})$ & SD & W (g) & SD & BW (mm) & SD & $\operatorname{BDmax}(\mathrm{mm})$ & SD & $\mathrm{BD}(\mathrm{mm})$ & SD & Cpd (mm) & SD \\
\hline $22^{\circ} \mathrm{C}$ & 32.66 & 1.60 & 0.349 & 0.04 & 4.773 & 0.32 & 6.736 & 0.36 & 5.695 & 0.37 & 3.011 & 0.19 \\
\hline $25^{\circ} \mathrm{C}$ & 32.29 & 2.51 & 0.335 & 0.07 & 4.744 & 0.43 & 6.493 & 0.57 & 5.554 & 0.58 & 3.004 & 0.30 \\
\hline $28^{\circ} \mathrm{C}$ & 32.71 & 1.82 & 0.347 & 0.05 & 4.882 & 0.24 & 6.770 & 0.45 & 5.789 & 0.44 & 2.961 & 0.23 \\
\hline $31^{\circ} \mathrm{C}$ & 33.11 & 2.06 & 0.357 & 0.07 & 4.816 & 0.48 & 6.663 & 0.54 & 5.666 & 0.47 & 2.933 & 0.24 \\
\hline
\end{tabular}


zebrafish, Widmer et al. (2006) studied the effect of hypoxia versus normoxia and Plaut and Gordon (1994) compared wild-type and cloned zebrafish. In the present study, the maximum relative critical swimming speed was estimated from 7.7 to $8.8 \mathrm{TL}$ $\mathrm{sec}^{-1}$ which is in agreement with the results of Widmer et al. (2006), who reported it between 8.5 and $9.5 \mathrm{SL} \mathrm{sec}^{-1}$, as this value is lowered if converted to $\mathrm{TL} \mathrm{sec}{ }^{-1}$. Plaut (2000) measured $R U_{\text {crit }}$ values around 12.6 TL $\mathrm{sec}^{-1}$ (after the appropriate adjustment from SL to TL), and Plaut and Gordon (1994) were unable to exhaust their wild-type specimens, but conclude that they swam more than $13 \mathrm{SL} \mathrm{sec}{ }^{-1}$. Similar results were described also by McClelland et al. (2006). The presented differences in $R U_{\text {crit }}$ values between these studies and also the present one, can be explained by either the different measuring techniques and apparatus used, or the higher swimming temperature maintained by the authors during the trials $\left(28^{\circ} \mathrm{C}\right)$.

There have been of course other studies on the effect of rearing temperature on swimming performance of other - mostly farmed marine - species. For example, Koumoundouros et al. (2009) studied the effect of two rearing temperatures on the swimming performance of European sea bass juveniles. In this study, the authors argued that fish raised in lower temperature $\left(15^{\circ} \mathrm{C}\right)$ performed better than the fish raised in higher temperature $\left(20^{\circ} \mathrm{C}\right)$. This is in contrast with our present results (where fish raised in higher temperature ultimately performed better than the others) but both studies suggest that the rearing temperature had a profound effect on the swimming capacity of fish at later stages.

There are two possible explanations for the observed effect. The influence of developmental temperature on the muscle ontogeny of the fish which has long been established (Johnston 1981, 1993, 2006; Johnston et al. 2009; Koumoundouros et al. 2009) appears to have a substantial effect on swimming performance. Different temperatures lead to variation in body muscle mass (in terms of size and number of muscle fibres) that directly affect swimming ability. Koumoundouros et al. (2009), showed that in the case of European sea bass, the best swimmers had relatively higher red muscle to white muscle ratio and more red muscle fibres than the others. In the case of zebrafish, Johnston et al. (2009) showed that the optimal embryonic temperature for fast muscle fibre recruitment (hyperplasia) is $26^{\circ} \mathrm{C}$, as in that temperature there were $18.8 \%$ more fast fibers than at $22^{\circ} \mathrm{C}$ and $13.7 \%$ more fibers than at $31^{\circ} \mathrm{C}$. After this phase, myotube formation stops and a new phase begins (hypertrophy) that consists of nuclear accretion and increase in fibre length and diameter (Johnston et al. 2004). Even though higher developmental temperature does not lead to increased number of fast muscle fibres, it is still possible that it affects the second phase of muscle formation, resulting in longer and thicker muscle fibres.

The second is that temperature in early life affects body shape (Georgakopoulou et al. 2007; personal unpublished results) and meristic count (Blaxter 1991; Georgakopoulou et al. 2007; personal unpublished results). Georgakopoulou et al. (2007), concluded that European sea bass juveniles reared in $15^{\circ} \mathrm{C}$ had more slender bodies than the ones reared in $20^{\circ} \mathrm{C}$, a fact that could explain the higher swimming performance of the former as observed by Koumoundouros et al. (2009).

In the present study, we tried to investigate whether there is a direct correlation between a single morphometric character and $R U_{c r i t}$. The fact that the examined morphometric characters do not significantly vary among the four temperature groups leads us to conclude that there is no such correlation between these size-related values and the observed differentiation of swimming performance. On the other hand, unpublished results of our team indicate that zebrafish grown in different temperatures tend to differ in both body shape and meristic character count, which is in agreement with the results of Georgakopoulou et al. (2007). It is logical to assume therefore that it is a combination of those characters (body shape in general) and it's variation among the different temperature regimes rather than the effect of a single one that eventually influences the swimming ability of a fish.

Acknowledgements The authors thank Maria Kampitaki for her valuable assistance during the experimental fish rearing and swimming trials. The present study was financed by the European Social Fund and National Resources (EPEAEK IIPYTHAGORAS I) to M.K.

\section{References}

Amsterdam A, Hopkins N (2006) Mutagenesis strategies in zebrafish for identifying genes involved in development and disease. Trends Genet 22:473-478 
Baroiller JF, Guiguen Y, Fostier A (1999) Endocrine and environmental aspects of sex differentiation in fish. Cell Mol Life Sci 55:910-931

Beamish FWH (1978) Swimming capacity. In: Hoar WS, Randall DJ (eds) Fish physiology, vol 7. Academic, New York, pp 101-187

Beaumont MW, Butler PJ, Taylor EW (2000) Exposure of brown trout, Salmo trutta, to a sub-lethal concentration of copper in soft acidic water: Effects upon muscle metabolism and membrane potential. Aquat Toxicol 51(2):259272

Blaxter JHS (1991) The effect of temperature on larval fishes. Neth J Zool 42:336-357

Brett JR (1964) The respiratory metabolism and swimming performance of young sockeye salmon. J Fish Res Board Can 21:1183-1226

Budick SA, O'Malley DM (2000) Locomotor repertoire of the larval zebrafish: swimming, turning and prey capture. J Exp Biol 203:2565

Cabral HN, Marques JF, Rego AL, Catarino AI, Figueiredo J, Garcia J (2003) Genetic and morphological variation of Synaptura lusitanica Capello, 1868, along the portuguese coast. J Sea Res 50:167-175

Dahlberg ML, Shumway DL, Doudoroff P (1968) Influence of dissolved oxygen and carbon dioxide on swimming performance of largemouth bass and Coho salmon. J Fish Res Board Can 25:49-70

Dickson KA, Donley JM, Sepulveda C, Bhoopat L (2002) Effects of temperature on sustained swimming performance and swimming kinematics of the chub mackerel Scomber japonicus. J Exp Biol 205:969

Divanach P, Papandroulakis N, Anastasiadis P, Koumoundouros G, Kentouri M (1997) Effect of water currents on the development of skeletal deformities in sea bass (Dicentrarchus labrax L.) with functional swimbladder during postlarval and nursery phase. Aquaculture 156:145-155

Drücker EG (1996) The use of gait transition speed in comparative studies of fish locomotion. Integr Comp Biol 36:555

Engeszer RE, Patterson LB, Rao AA, Parichy DM (2007) Zebrafish in the wild: a review of natural history and new notes from the field. Zebrafish 4:21-40

Franklin CE, Wilson RS, Davison W (2003) Locomotion at -1.01 c: Burst swimming performance of five species of antarctic fish. J Therm Biol 28:59-65

Froese R, Pauly D (eds) (2010) FishBase: World Wide Web electronic publication. http://fishbase.org/Summary/Species Summary.php? $\mathrm{ID}=4653$. Accessed at 16 June 2010

Fuiman L, Batty R (1997) What a drag it is getting cold: partitioning the physical and physiological effects of temperature on fish swimming. J Exp Biol 200:1745

Fukuhara O (1990) Effects of temperature on yolk utilization, initial growth, and behaviour of unfed marine fish-larvae. Mar Biol 106:169-174

Georgakopoulou E, Sfakianakis DG, Kouttouki S, Divanach P, Kentouri M, Koumoundouros G (2007) The influence of temperature during early life on phenotypic expression at later ontogenetic stages in sea bass. J Fish Biol 70:278291

Gerlai R (2003) Zebra fish: an uncharted behavior genetic model. Behav Genet 33:461-468
Gibson S, Johnston IA (1995) Temperature and development in larvae of the turbot Scophthalmus maximus. Mar Biol 124:17-25

Hammer C (1995) Fatigue and exercise tests with fish. Comp Biochem Physiol A 112:1-20

Herzig A, Winkler H (1986) The influence of temperature on the embryonic development of three cyprinid fishes, Abramis brama, Chalcalburnus chalcoides mento and Vimba vimba. J Fish Biol 28:171-181

Hochachka PW (1987) Limits: how fast and how slow muscle metabolism can go. Adv Myochem 1:3-12

Howard TE (1975) Swimming performance of juvenile Coho salmon (Oncorhynchus kisutch) exposed to bleached kraft pulpmill effluent. J Fish Res Board Can 32:789-793

Johnston IA (1981) Structure and function of fish muscles. Symp Zool Soc Lond 48:71-113

Johnston IA (1993) Temperature influences muscle differentiation and the relative timing of organogenesis in herring (Clupea harengus) larvae. Mar Biol 116:363-379

Johnston IA (2006) Environment and plasticity of myogenesis in teleost fish. J Exp Biol 209:2249

Johnston I, Abercromby M, Vieira V, Sigursteindottir R, Kristjansson B, Sibthorpe D, Skulason S (2004) Rapid evolution of muscle fibre number in post-glacial populations of arctic charr Salvelinus alpinus. J Exp Biol 207:4343

Johnston IA, Lee HT, Macqueen DJ, Paranthaman K, Kawashima C, Anwar A, Kinghorn JR, Dalmay T (2009) Embryonic temperature affects muscle fibre recruitment in adult zebrafish: Genome-wide changes in gene and microRNA expression associated with the transition from hyperplastic to hypertrophic growth phenotypes. J Exp Biol 212:1781

Jones DR, Kiceniuk JW, Bamford OS (1974) Evaluation of the swimming performance of several fish species from the Mackenzie river. J Fish Res Board Can 31:1641-1647

Korsmeyer KE, Dewar H, Lai NC, Graham JB (1996) Tuna aerobic swimming performance: physiological and environmental limits based on oxygen supply and demand. Comp Biochem Physiol B 113:45-56

Koumoundouros G, Gagliardi F, Divanach P, Boglione C, Cataudella S, Kentouri M (1997a) Normal and abnormal osteological development of caudal fin in Sparus aurata L. fry. Aquaculture 149:215-226

Koumoundouros G, Oran G, Divanach P, Stefanakis S, Kentouri M (1997b) The opercular complex deformity in intensive gilthead sea bream (Sparus aurata 1.) larviculture. Moment of apparition and description. Aquaculture 156:165-177

Koumoundouros G, Divanach P, Anezaki L, Kentouri M (2001a) Temperature-induced ontogenetic plasticity in sea bass (Dicentrarchus labrax). Mar Biol 139:817-830

Koumoundouros G, Divanach P, Kentouri M (2001b) The effect of rearing conditions on development of saddleback syndrome and caudal fin deformities in Dentex dentex (L.). Aquaculture 200:285-304

Koumoundouros G, Pavlidis M, Anezaki L, Kokkari C, Sterioti A, Divanach P, Kentouri M (2002a) Temperature sex determination in the European sea bass, Dicentrarchus labrax (L., 1758) (Teleostei, Perciformes, Moronidae): critical sensitive ontogenetic phase. J Exp Zool 292:573579 
Koumoundouros G, Sfakianakis D, Divanach P, Kentouri M (2002b) Effect of temperature on swimming performance of sea bass juveniles. J Fish Biol 60:923-932

Koumoundouros G, Ashton C, Sfakianakis D, Divanach P, Kentouri M, Anthwal N, Stickland N (2009) Thermally induced phenotypic plasticity of swimming performance in European sea bass Dicentrarchus labrax juveniles. J Fish Biol 74:1309-1322

Lein I, Holmefjord I, Rye M (1997) Effects of temperature on yolk sac larvae of Atlantic halibut (Hippoglossus hippoglossus L.). Aquaculture 157:123-135

Levin ED, Swain HA, Donerly S, Linney E (2004) Developmental chlorpyrifos effects on hatchling zebrafish swimming behavior. Neurotoxicol Teratol 26:719-723

Lindsey CC (1988) Factors controlling meristic variation. In: Hoar WS, Randall DJ (eds) Fish physiology, vol 11. Academic, New York, pp 197-274

Malek RL, Sajadi H, Abraham J, Grundy MA, Gerhard GS (2004) The effects of temperature reduction on gene expression and oxidative stress in skeletal muscle from adult zebrafish. Comp Biochem Physiol C 138:363-373

McClelland GB, Craig PM, Dhekney K, Dipardo S (2006) Temperature- and exercise-induced gene expression and metabolic enzyme changes in skeletal muscle of adult zebrafish (Danio rerio). J Phys 577:739

Ojanguren AF, Brana F (2000) Thermal dependence of swimming endurance in juvenile brown trout. J Fish Biol 56:1342-1347

Pakkasmaa S, Piironen J (2001) Morphological differentiation among local trout (Salmo trutta) populations. Biol J Linn Soc 72:231-239

Pavlidis M, Koumoundouros G, Sterioti A, Somarakis S, Divanach P, Kentouri M (2000) Evidence of temperaturedependent sex determination in the European sea bass (Dicentrarchus labrax L.). J Exp Zool 287:225-232

Plaut I (2000) Effects of fin size on swimming performance, swimming behaviour and routine activity of zebrafish Danio rerio. J Exp Biol 203:813

Plaut I, Gordon M (1994) Swimming metabolism of wild-type and cloned zebrafish Brachydanio rerio. J Exp Biol 194:209

Polo A, Yufera M, Pascual E (1991) Effects of temperature on egg and larval development of Sparus aurata L. Aquaculture 92:367-375

Ramsay J, Feist G, Varga Z, Westerfield M, Kent M, Schreck C (2009) Whole-body cortisol response of zebrafish to acute net handling stress. Aquaculture 297:157-162

Randall DJ, Tsui TKN (2002) Ammonia toxicity in fish. Mar Pollut Bull 45:17-23

Reidy SP, Kerr SR, Nelson JA (2000) Aerobic and anaerobic swimming performance of individual Atlantic cod. J Exp Biol 203:347-357

Silva A (2003) Morphometric variation among sardine (Sardina pilchardus) populations from the northeastern Atlantic and the western Mediterranean. ICES J Mar Sci 60:1352
Sokal RS, Rohlf FJ (1995) Biometry: the principles and practice of statistics in biological research. WH Freeman and Co., New York

Spence R, Gerlach G, Lawrence C, Smith C (2008) The behaviour and ecology of the zebrafish, Danio rerio. Biol Rev Camb Philos Soc 83(1):13-34

Steffensen J, Farrell AP (1998) Swimming performance, venous oxygen tension and cardiac performance of coronary-ligated rainbow trout, Oncorhynchus mykiss, exposed to progressive hypoxia. Comp Biochem Physiol A 119:585-592

Talwar PK, Jhingran AG (1991) Inland fishes of India and adjacent countries, vol 1. Oxford \& IBH Pub. Co., Rotterdam

Tudela S (1999) Morphological variability in a Mediterranean, genetically homogeneous population of the European anchovy, Engraulis encrasicolus. Fish Res 42:229-243

Turan C (2004) Stock identification of Mediterranean horse mackerel (Trachurus mediterraneus) using morphometric and meristic characters. ICES J Mar Sci 61:774

Westerfield M (1995) The zebrafish book: a guide for the laboratory use of zebrafish (Danio rerio). University of Oregon Press, Eugene

Wicks BJ, Joensen R, Tang Q, Randall DJ (2002) Swimming and ammonia toxicity in salmonids: The effect of sub lethal ammonia exposure on the swimming performance of Coho salmon and the acute toxicity of ammonia in swimming and resting rainbow trout. Aquat Toxicol 59:55-69

Widmer S, Moore FBG, Bagatto B (2006) The effects of chronic developmental hypoxia on swimming performance in zebrafish. J Fish Biol 69:1885-1891

Wieser W, Kaufmann R (1998) A note on interactions between temperature, viscosity, body size and swimming energetics in fish larvae. J Exp Biol 201:1369

Wilkes D, Xie SQ, Stickland NC, Alami-Durante H, Kentouri M, Sterioti A, Koumoundouros G, Fauconneau B, Goldspink G (2001) Temperature and myogenic factor transcript levels during early development determines muscle growth potential in rainbow trout (Oncorhynchus mykiss) and sea bass (Dicentrarchus labrax). J Exp Biol 204:2763-2771

Williams IV, Brett JR (1987) Critical swimming speed of Fraser and Thompson river pink salmon (Oncorhynchus gorbuscha). Can J Fish Aquat Sci 44:348-356

Wilson RS, Kuchel LJ, Franklin CE, Davison W (2002) Turning up the heat on subzero fish: thermal dependence of sustained swimming in an Antarctic notothenioid. J Therm Biol 27:381-386

Wimberger PH (1992) Plasticity of fish body shape. The effects of diet, development, family and age in two species of Geophagus (Pisces; Cichlidae). Biol J Linn Soc 45:197-218

Young PS, Swanson C, Cech JJ Jr (2004) Photophase and illumination effects on the swimming performance and behavior of five California estuarine fishes. Copeia 2004:479-487 